\title{
ASO Author Reflections: Multimodality Treatment in Esophageal Signet Ring Cell Adenocarcinoma
}

\author{
Sander J. M. van Hootegem, BSc $\mathbb{C}$, and Bas. P. L. Wijnhoven, MD, PhD \\ Department of Surgery, Erasmus MC, University Medical Center, Rotterdam, The Netherlands
}

\section{PAST}

The aggressive and infiltrating behaviour of signet ring cell (SRC) tumours may be associated with poor prognosis. ${ }^{1}$ Although multimodality treatment has become the standard of care for oesophageal and junctional adenocarcinoma, the role of neoadjuvant therapy has been under debate for SRC tumours. Still little is known about the exact impact of SRC histology on the efficacy of multimodality treatment in oesophageal and junctional adenocarcinoma. ${ }^{1,2} \mathrm{We}$, therefore, assessed the impact of SRC histology on response to neoadjuvant therapy and survival.

\section{PRESENT}

Despite SRC histology not being an independent predictor for overall or disease-free survival in this study, tumours with an SRC component had a higher rate of irradical (R1/R2) resections and more advanced pathological T-stage after neoadjuvant therapy compared with nonSRC tumours. ${ }^{3}$ SRC tumours had a higher rate of irradical resections and a more advanced pathological $\mathrm{T}$-stage, resulting in worse locoregional recurrence-free survival after receiving $\mathrm{nCT}$. On the contrary, following nCRT, no

ASO Author Reflections is a brief invited commentary on the article, The Impact of Signet Ring Cell Differentiation on Outcome in Patients with Oesophageal and Gastro-oesophageal Junction Adenocarcinoma. Ann Surg Oncol. 2019;26:2375-84.

(C) The Author(s) 2019

First Received: 5 September 2019;

Published Online: 21 October 2019

S. J. M. van Hootegem, BSc

e-mail: s.vanhootegem@erasmusmc.nl statistically significant differences were found between groups for overall and disease-free survival and pathological characteristics. Moreover, the SRC group had worse disease-free survival compared with the non-SRC group after receiving nCT. These results indicate that nCRT could achieve comparable locoregional control, recurrence rates, and survival as in patients with non-SRC tumours. Given the behavioural features of SRCs, locoregional control could be of major importance.

\section{FUTURE}

As biopsies are not always representative for the pheno- and genotype of the entire tumour, they may not be accurate enough to determine the percentage of SRC present. ${ }^{1}$ However, Bekkar et al. compared nCRT with surgery alone in $>50 \%$ SRC tumours and found a significant survival benefit and lower rates of recurrence after nCRT. ${ }^{4}$ This study underlines the findings of the present study that favourable oncologic outcomes after nCRT could be achieved in SRC tumours, independent of percentage.

Possible intensification of locoregional therapy, however, may still be needed, and larger, prospective studies should be conducted stratifying for SRC histology to establish nCRT as optimal treatment regimen for oesophageal SRC tumours.

DISCLOSURES The authors have no conflicts of interest to disclose.

OPEN ACCESS This article is distributed under the terms of the Creative Commons Attribution 4.0 International License (http://crea tivecommons.org/licenses/by/4.0/), which permits unrestricted use, distribution, and reproduction in any medium, provided you give appropriate credit to the original author(s) and the source, provide a link to the Creative Commons license, and indicate if changes were made. 


\section{REFERENCES}

1. Nafteux PR, Lerut TE, Villeneuve PJ, et al. Signet ring cells in esophageal and gastroesophageal junction carcinomas have a more aggressive biological behavior. Ann Surg. 2014;260(6):1023-9.

2. Bleaney CW, Barrow M, Hayes S, Ang Y. The relevance and implications of signet-ring cell adenocarcinoma of the oesophagus. J Clin Pathol. 2018;71(3):201-6.

3. van Hootegem SJM, Smithers BM, Gotley DC, et al. The impact of signet ring cell differentiation on outcome in patients with oesophageal and gastro-oesophageal junction adenocarcinoma. Ann Surg Oncol. 2019;26:2375-84.

4. Bekkar S, Gronnier C, Messager M, et al. The impact of preoperative radiochemotherapy on survival in advanced esophagogastric junction signet ring cell adenocarcinoma. Ann Thorac Surg. 2014;97(1):303-10.

Publisher's Note Springer Nature remains neutral with regard to jurisdictional claims in published maps and institutional affiliations. 